\title{
PENGARUH ROA, DER, NPM TERHADAP HARGA SAHAM PADA SEKTOR KEUANGAN (FINANCE) YANG TERDAFTAR DI BEI PERIODE 2015-2019
}

\author{
Risma Uli Manulang ${ }^{1)}$, Indah Satrya Panjaitan ${ }^{2)}$, Diana Safitri Damanik ${ }^{3)}$, \\ Ester Manalu ${ }^{4)}$, Januardin ${ }^{5}$ * \\ $\mathbf{1 , 2 , 3 , 4 , 5 )}$ Universitas Prima.Indonesia, Indonesia \\ Email : uli.risma22@gmail.com \\ Corresponding author : januardin@unprimdn.ac.id
}

\begin{abstract}
Abstrak
Penelitian ini bertujuan untuk mengkaji dan menganalisis dampak ROA,DER,NPM terhadap harga saham pada sektor keuangan (finance) yang terdaftar di BEI periode ( 2015 - 2019 ). Populasi penelitian dalam penelitian ini adalah 45 perusahaan dengan metode teknik pengambilan Purposive Sampling sebanyak 12 perusahaan pada sub sektor keuangan di BEI (2015-2019). Penelitian ini menggunakan metode kuantitatif, jenis penelitian deskriptif, sifat penelitian deduktif, metode pengumpulan data, serta tinjauan pustaka. Uji coba pengkajian ini menggunakan uji $T$ dan uji $F$. Hasil pengujian dari penelitian ini menunjukkan bahwa pada saat yang sama ROA, DER, NPM berpengaruh pada harga saham pada perusahaan sub sektor keuangan (finance) yang terdaftar di Bursa Efek Indonesia periode 2015-2019.
\end{abstract}

Kata kunci : ROA ; DER ; NPM ; dan Harga"Saham

\section{Abstract}

This study aims to examine and analyze the impact of ROA, DER, NPM on stock prices in the financial sector listed on the IDX for the period (2015-2019). The research population in this test is 45 companies with a purposive sampling method as many as 12 companies in the financial sub-sector on the IDX (2015-2019). This research uses quantitative methods, descriptive research types, the nature of deductive research, data collection methods, and literature. The trial of this study uses the T test and the F test. The test results from this study show that at the same time ROA, DER, NPM affect "on stock prices" in financial sub-sector companies listed on the Stock Exchange. Indonesian Securities for the period 2015-2019.

Keywords : ROA ; DER ; NPM ; Stock Price

\section{PENDAHULUAN}

Sektor keuangan yaitu perusahaan jasa yang bergerak dibidang yang berkaitan dengan uang dan sudah masuk dalam perusahaan publik yang telah terdaftar di BEI dan dikelompokkan menjadi beberapa sub sektor, yaitu sub sektor bank, lembaga pembiayaan, perusahaan efek, asuransi dan sub sektor lain sebagainya. (Kayo, 2016).

PT Bank Negara Indonesia Tbk pada tahun 2017-2018 total aset mengalami peningkatan dari 709.330.000.000 menjadi 868.572.000.000 sedangkan harga saham mengalami penurunan dari 9.900 menjadi 8.800 di mana menurut teori, apabila total aset meningkat, maka harga saham juga meningkat.

PT. Bank Central Asia Tbk pada tahun 2015 - 2016 kewajiban mengalami peningkatan dari 504.748.000.000 menjadi 564.024.000.000 sedangkan harga saham naikdari 13.300 menjadi 15.500 dimana menurut teori, apabila kewajiban meningkat maka harga saham akan menurun.

PT.Bank Mandiri Tbk pada tahun 2017-2108 laba bersih mengalami peningkatan dari 20.639.683.000.000 menjadi 25.015.021.000.000 sedangkan harga 
saham mengalami penurunan dari 8.000 menjadi 7.375, menurut teori jika laba bersih meningkat maka hargaa saham juga akan naik.

\section{TINJAUAN PUSTAKA}

\section{Pengertian Return On Asset}

Digunakan untuk melihat besarnya jumlah laba bersih dari dana yang ditanamkan pada aktiva. Hery (2015:193).

Return On Asset $=$ Laba Bersih

\section{PENJUALAN BERSIH}

Pengertian Debt to Equity Ratio ( DER ) adalah Rasio yang digunakan untuk melihat perbandingan utang dan modal. Semakin sedikit utang suatu perusahaan maka semakin terjaminkualitas perusahaan tersebut (Fakhruddin dan Hardianto).

Indikator Debt to Equity Ratio ( DER ) adalah Rasio utang terhadap ekuitas yang dapat dihitung dengan cara, dengan ekuitas atau modal. Berikut adalah rumus DER :

$$
\text { DER }=\frac{\text { Total Utang }}{\text { Ekuitas }}
$$

Net Profit Margin ( NPM ) digunakan untuk melihat persentase keuntungan perusahaan pada penjualan bersih.

Menurut Kasmir (2012:200), NPM digunakan untuk melihat ukuran keuntungan suatu perusahaan dari perbandingan laba setelah pajak dengan penjualan. Rasio ini menunjukan penda patan bersih atas penjualan dengan rumus:

$$
N P M=\frac{\text { Laba bersih }}{\text { Penjualan bersih }}
$$

\section{Pengertian Harga Saham}

Saham sendiri memiliki arti bukti kepemilikan atas suatu nilai perusahaan, yang mana kebanyakan para investor berinvestasi pada saham. Sedangkan harga saham adalah harga yang harus dibayarkan seseorang yang ingin memiliki bukti kepemilikan perusahaan tersbut. Semakin bagus kinerja sebuah perusahaan maka akan semakin tinggi harga dari bukti kepemilikan tersebut (saham).

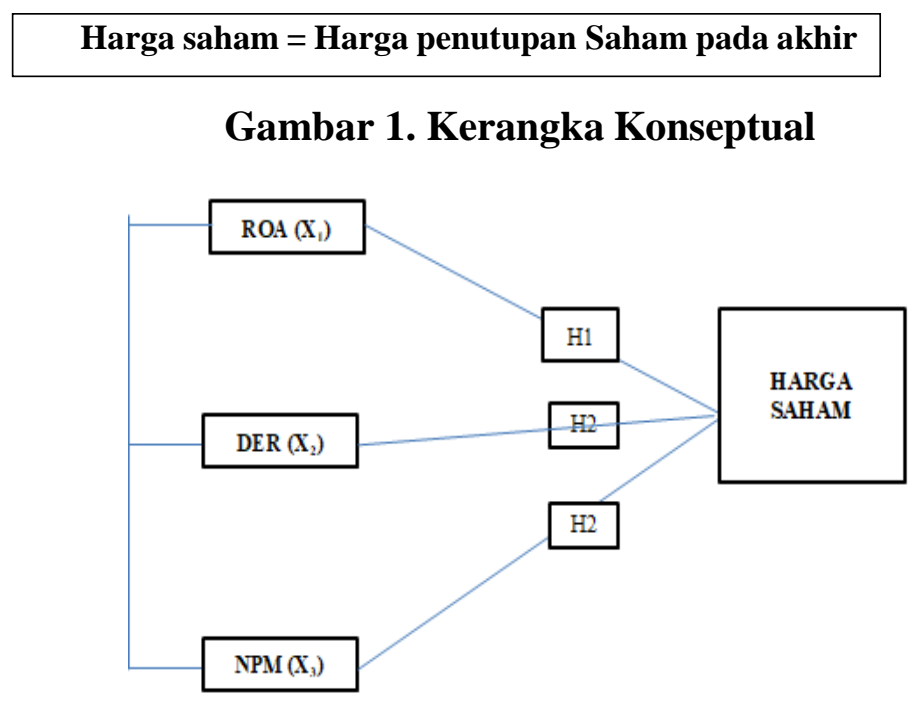




\section{Hipotesis Penelitian}

Hipotesis Penelitian merupakan dugaan sementara terhadap masalah yangakan diteliti dan jawaban itu masih akan diuji secara empiriskebenarannya . Hipotesis dalam penelitian ini adalah :

1. H1: ROA berpengaruh secara parsial pada harga saham sub sektor keuangan di BEI periode 2015-2019.

2. H2: DER berpengaruh secara parsial pada harga saham sub sektor keuangan diBEI periode 2015-2019.

3. H3: NPM berpengaruh secara parsial pada harga saham sub sektor keuangan di BEI periode 2015-2019.

4. H4: ROA, DER, NPM berpengaruh secara simultan pada harga saham sub sektor keuangan di BEI periode 2015-2019.

\section{METODE PENELITIAN}

\section{Tempat dan Waktu Penelitian}

Penelitian ini dilakukan pada perusahaan sektor keuangan yang terdaftar di BEI pada periode 2015-2019 diambil dari situs www.idx.co.id.

\section{Pendekatan Penelitian}

Pendekatan penelitian ini menggunakan pendekatan kuantitatif. Sebagaimana dikemukakan oleh Kasiram (2008:149) metode kuantitatif digunakan untuk menganalisis data berupa angka.

\section{Jenis Penelitian}

Pengujian ini menggunakan jenis deskriptif. Penelitian deskriptif digunakan untuk menjelaskan objek yang diteliti melalui data yang terkumpul (Sugiyono2011:29).

\section{Populasi dan Sampel}

Populasi adalah keseluruhan objek penelitian (Bugin 2000 : 40). Populasi dalam penelitian ini adalah Perusahaan Sub Sektor Keuangan yang tercatat di BEI periode 2015 2019 .Sampel merupakan bagian dari populasi (Arikunto 2006:131). Penentuan sampel dalam pengkajian ini :

1. Perusahaan sub sektor keuangan yang terdaftar di BEI periode 2015-2019.

2. Perusahaan sub sektor keuangan yang mempublish laporan keuangan secara berturut turut periode2015-2019.

3. Perusahaan sub sektor keuangan yang mencantumkan harga saham periode 2015-2019.

Tabel 1. Kriteria Pemilihan Sampel

\begin{tabular}{|c|c|c|}
\hline No & Kriteria & Jumlah Sampel \\
\hline 1. & $\begin{array}{l}\text { Perusahaan sub sektorperbankan yang tercatat di Bursa Efek } \\
\text { Indonesia selama periode 2015-2019 }\end{array}$ & 45 \\
\hline 2. & $\begin{array}{l}\text { Penusahaan sub sektor perbankan yang tidak mempublish } \\
\text { laporan keuangan secara benuntan selama penode } 2015 \text { - } \\
2019\end{array}$ & (9) \\
\hline 3. & $\begin{array}{l}\text { Perusahaan sub sektor perbankan yang tidak mencantumkan } \\
\text { harga saham }\end{array}$ & (24) \\
\hline \multicolumn{2}{|c|}{ Totalperusahaan sub sektor perbankan yang memenuhi syarat } & 12 \\
\hline \multicolumn{2}{|c|}{ Jumlah sampel dalampenelitian $12 \times 5$ tahum } & 60 \\
\hline
\end{tabular}




\section{Teknik Pengumpulan Data}

Teknik pengumpulan data dalam pengkajian ini diambil dari tinjauan pustaka serta mengakses situs resmi BEI.

\section{Jenis dan Sumber Data}

Pengkajian ini menggunakan jenis data sekunder yang didapat dari sumber lain sehingga peneliti mengumpulkan data untuk diteliti.

Tabel 2. Definisi Operasional Variabel Penelitian

\begin{tabular}{|c|c|c|c|}
\hline Variabel & Definisi & Indikation & Skcala Uksur \\
\hline $\begin{array}{l}\text { Return } \\
\text { Onasset } \\
\text { (x1) }\end{array}$ & $\begin{array}{l}\text { Rasio yang digunakan untuk } \\
\text { mengukur kapasitas modal } \\
\text { menempatkan sumbr daya } \\
\text { ke dalam sumber daya } \\
\text { secara umum untuk } \\
\text { menciptakan keuntungan } \\
\text { bersih } \\
\text { sumber : } V \text {. Wirayna Sujarweni } \\
\text { [2019: 114] }\end{array}$ & ROA $=\frac{\text { Laba Bersih }}{\text { Total Aset }}$ & Rasio \\
\hline $\begin{array}{l}\text { Debt To } \\
\text { Equity } \\
\text { Ratio } \\
\text { (xz) }\end{array}$ & $\begin{array}{l}\text { Loel G. Siegel dan Jae K. Shim } \\
\text { suatu tindakan yang digunakan } \\
\text { dalam memyelidiki laporan } \\
\text { anggaran untuk menunjukkan } \\
\text { ukuran jaminan yang dapat } \\
\text { diakses oleh pemberi pinjaman. } \\
\text { sumber : Irham Fahmi [201B: } \\
\text { T2 ] }\end{array}$ & DER $=\frac{\text { Total Utang }}{\text { Ekuitas }}$ & Rasio \\
\hline $\begin{array}{l}\text { Net } \\
\text { Profit } \\
\text { Margin } \\
\text { (x3) }\end{array}$ & $\begin{array}{l}\text { Rasio yang digunakan untuk } \\
\text { mengukur keuntungan } \\
\text { bersih setelah biaya } \\
\text { kemudian dikontraskan dan } \\
\text { volume penawaran. } \\
\text { sumber : } V \text {. Wirayna Sujarweni } \\
\text { [2019: } 114]\end{array}$ & NPM $=\frac{\text { Laba bersih }}{\text { Penjualan bersíh }}$ & Rasio \\
\hline $\begin{array}{l}\text { Harga } \\
\text { Snhama } \\
\text { (Y) }\end{array}$ & $\begin{array}{l}\text { Harga yang diselesaikan dari } \\
\text { interaksi antara dealer dan } \\
\text { permbeli saham }\end{array}$ & $\begin{array}{l}\text { Hanga Saham } \\
\text { Penutupan Hartano } \\
\{2016: 179\}\end{array}$ & Rasio \\
\hline
\end{tabular}

\section{Uji Asumsi Klasik}

\section{Uji Normalitas}

Dilakukan untuk mengetahui apakah dalam model regresi, faktor bebas dan variabel terikat atau kultur memiliki sebaran yang khas atau tidak biasa Ghozali (2016)

\section{Uji Multikolinealitas}

Seperti yang ditunjukkan oleh Ghozali (2018,hlm.105), motivasi dibalik uji multikolinearitas digunakan untuk menguji apakah model regresi ada hubunga antara faktor-faktor bebas. Model relaps yang layak memiliki model dimana tidak memiliki hubungan dengan faktor bebas. Uji autokorelasi digunakan untuk mengetahui apakah pada model relaps terdapat hubungan kesalahan yang membingungkan pada periode $t$ dan kesalahan membingungkan pada periode 1 (Ghozali,2018:11).

\section{Uji Heteroskedatisitas}

Uji Heteroskedastisitas Ghozali ( 2018 :135) mengatakan bahwa uji heteroskedastisitas berarti untuk melihat apakah dalam model regresi terdapat disparitas fluktuasi dari residual satu persepsi ke persepsi lainnya.

\section{Model Analisis Dan Penelitian}

Menurut Ardhana12 ( dalam Lexy J. Moleong 2002 : 103 ) yaitu cara untuk mendapatkan 
informasi, menyusunnya menjadi contoh, klasifikasi, dan unit penggambaran dasar.

\section{Koefisian Determinasi}

Koefisien penjaminan (R2) yaitu instrumen untuk mengukur seberapa luas kapasitas model dalam mengklarifikasi keragaman variabel terikat. Ghozali ( 2012 : 97 ).

\section{Pengujian Hipotesis Secara Persial (Uji T)}

Pengujian ini dimaksudkan untuk menguji seberapa berpengaruh faktor bebas terhadap variabel terikat adalah dengan melihat tabel dan thitung.

\section{Pengujian Hipotesis Secara Simultan (Uji F)}

Uji F ( uji simultan ) adalah dengan membandingkan nilai $F$ hasil perhitungan dengan nilai $\mathrm{F}$ menurut table. Apabila nilai $\mathrm{F}$ hitung lebih besar dari pada nilai $\mathrm{F}$ table, maka hipotesis alternative menyatakan bahwa semua variabel independen secara serentak dan signifikan mempengaruh variabel dependen .

\section{HASIL DAN PEMBAHASAN}

\section{Statistik Deskriptif}

Pengujian ini bertujuan untuk memahami tren nilai terkecil (minimum), dan nilai terbesar (maksimum), nilai rata - rata (mean), sehingga penulis dapat memaparkan hasil penelitian berupa bilangan/ angka ke dalam penelitian ini.

\begin{tabular}{|l|l|l|l|l|l|}
\hline & N & Minimum & Maximum & Mean & Std. Deviation \\
\hline ROA & 95 & .00 & .14 & .0265 & .02286 \\
DER & 95 & .89 & 8.96 & 1.8027 & .83896 \\
NPM & 95 & .00 & 2.30 & 1.5744 & .22057 \\
HARGA SAHAM & 95 & 3.91 & 10.42 & 6.6767 & 1.72533 \\
Valid N (listwoise) & 95 & & & & \\
\hline
\end{tabular}

Sumber data dari tabel diatas dapat diartikan bahwa:

1. Variabel bebas ROA dengan $\mathrm{N}=95$, memperlihatan nilai minimum $=0,00$, nilai maksimum $=0,14$ nilai mean $=0.0265$ dan nilai standar devisiasi $=0,02286$ pada perusahaan PT Bank Negara Indonesia Tbk.

2. Variabel bebas DER dengan $\mathrm{N}=95$, memperlihatkan nilai minimum $=0,89$, nilai maksimum $=8.96$, nilai mean $=1,8027$ dan nilai standar devisaisi $=0,83896$ pada perusahaan PT. Bank Central Asia Tbk.

3. Variabel bebas NPM dengan $\mathrm{N}=95$, memperlihatkan nilai minimum $=0,00$, nilai maksimum $=2,30$, nilai mean $=1,5744$ dan nilai standar devisias $=0,22057$ pada perusahaan PT. Bank Mandiri Tbk.

4. Variabel terikat Harga Saham dengan $\mathrm{N}=95$, memperlihatkan nilai minimum=3,91, nilai maksimum $=10,42$, nilai mean $=6,6767$ dan nilai standar devisiasi $=1,72533$ pada perusahaan PT. Bank Central Asia Tbk. 


\section{Hasil Uji Asumsi Klasik Uji Normalitas}

\section{Gambar 2. Uji Normalitas Histogram}

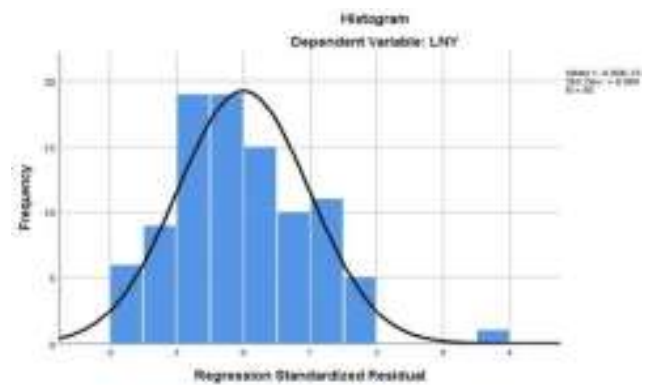

Pada gambar histogram setelah diubah/di transformasikan, yang berarti bahwa data residual berdistribuisi normal.grafik histogram menunjukkan garis kurva berbentuk lonceng.

\section{Gambar 3. Uji Normalitas P-Plot}

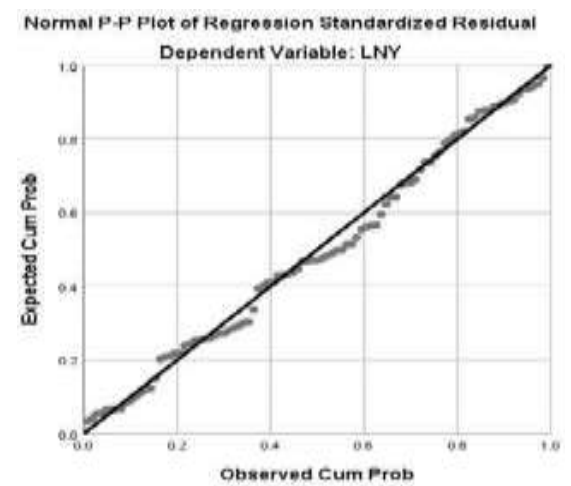

Pada gambar di atas $\mathrm{P}$ - p plot terlihat titik - titik menyebar mendekati garis diagonal sehingga dapat disimpulkan ROA (X1), DER(X2), NPM (X3) dan Harga Saham (Y) data dalam model regresi berdistribusi normal.

\section{Tabel 3. UJI NORMALITAS KOLMOGOROV-SMIRNOV}

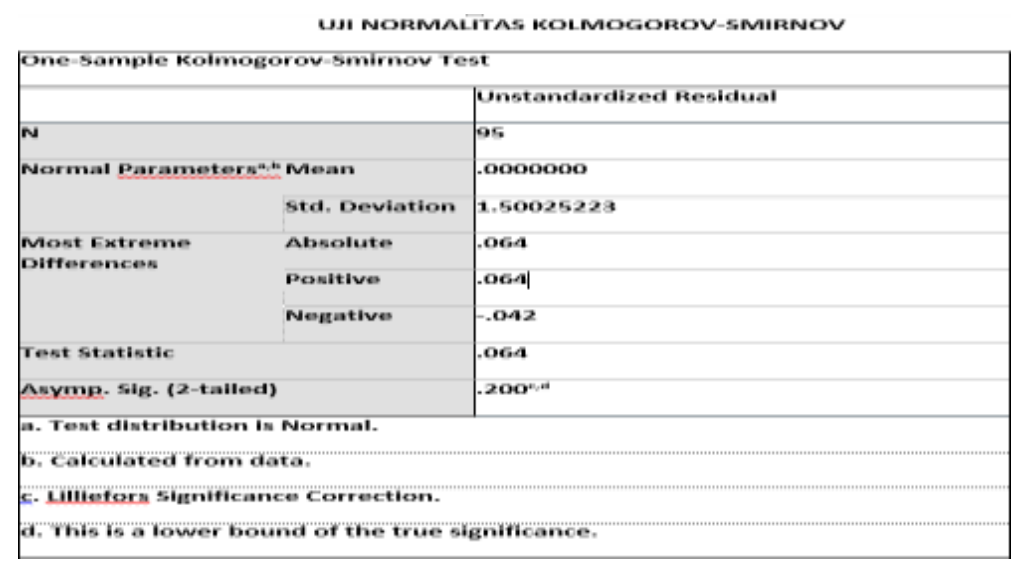

Dari tabel diatas dapat dilihat Kolmogorov- Smirnov menunjukkan nilai signifikan 0,200>0,05 dengan demikian dapat disimpulkan bahwa dalam hasil uji statistik 
Kolmogor ov- Smirnov data berdistribusi normal.

\section{Uji Multikolinieritas}

Ghozali (2013:103), Uji multikolinieritas digunakan untuk memastikan apakah model regresi ditemukan memiliki hubungan dengan variable indenpenden.

Tabel 4. Uji Multikolinieritas

\begin{tabular}{|c|c|c|c|c|}
\hline \multirow[b]{2}{*}{ Wodel } & & \multirow[b]{2}{*}{ Sig. } & \multicolumn{2}{|c|}{ Collinearity Statisfics } \\
\hline & & & Tolerance & VIF \\
\hline \multirow[t]{4}{*}{1} & (Constant) & .000 & & \\
\hline & $\mathrm{ROA}$ & .000 & .687 & 1.456 \\
\hline & DER & .918 & .997 & 1.003 \\
\hline & NPM & .568 & .686 & 1.458 \\
\hline
\end{tabular}

Dari hasil pengujian pada tabel uji multikolonieritas selanjutnya menyatakan bahwa :

1. Variabel ROA (X1) $0,687 \geq 0,10$ dan nilai VIf $\leq 10$.

2. Variabel DER (X2) $0,997 \geq 0,10$ dan nilai $\mathrm{VIF} \leq 10$.

3. Variabel NPM (X3) $0,686 \geq 0,10$ dan nilai $\mathrm{VIF} \leq 10$.

Uji Autokorelasi

Ghozali (2013:107) Uji ini bermaksud untuk memeriksa apakah ada hubungan antara kesalahan pengganggu tahun ini dengan tahun sebelumnya.

Tabel 5. Uji Autokorelasi

\begin{tabular}{|c|c|c|c|c|c|}
\hline \multicolumn{6}{|c|}{ Model Summary ${ }^{b}$} \\
\hline Model & $\mathrm{R}$ & R Square & $\begin{array}{c}\text { Adjusted R } \\
\text { Square } \\
\end{array}$ & $\begin{array}{c}\text { Std. Error of the } \\
\text { Estimate }\end{array}$ & Durbin-Watson \\
\hline 1 & $.494^{\mathrm{a}}$ & .244 & .219 & 1.52478 & 2.086 \\
\hline \multicolumn{6}{|c|}{ a. Predictors: (Constant), LNX3, LNX2, LNX1 } \\
\hline \multicolumn{6}{|c|}{ b. Dependent Variable: LNY } \\
\hline
\end{tabular}

Tabel uji autokorelasi diatas memperlihatkan nilai statistik $\mathrm{dw}=2.086 \mathrm{dan} \mathrm{du}=1.7316$ yaitu :1.7316 < $2.086<2.2684$ nilai DW 2.086 lebih besar dari 1.7316 dan lebih kecil dari $(4-1.7316)=2.2684$ dengan berarti bahwa model terbebas dari autokorelasi.

\section{Uji Heteroskedastisitas}

Ghozali (2013: 137) pengkajian ini bermaksud untuk melihat apakah adanya terjadi variasi pada hasil residual pada suatu waktu pemeriksaan ke pemeriksaan selanjutnya. 


\section{Gambar 4. Uji Heteroskedastisitas}

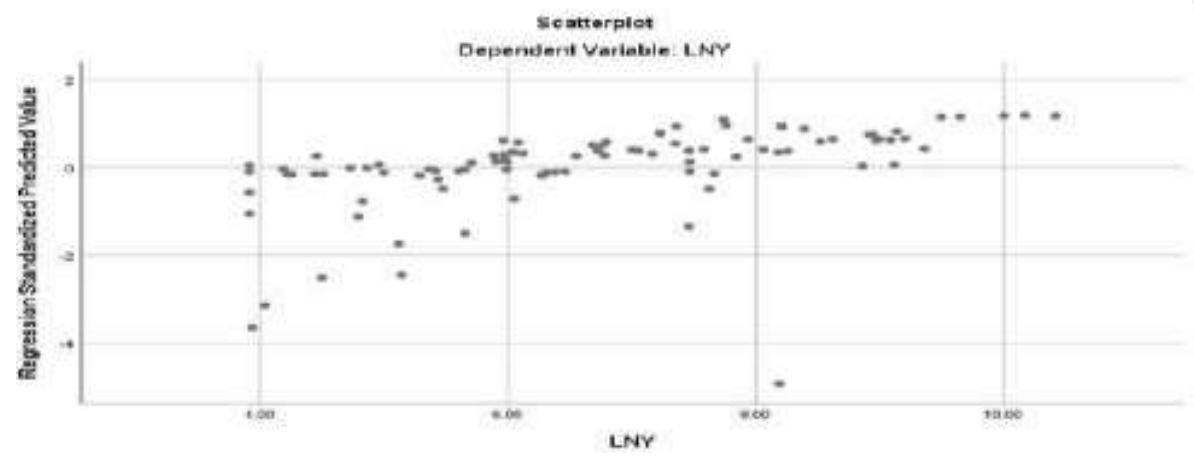

Pada uji diatas, menunjukkan bahwa titik- titik tersebar secara acak baik diatas maupun dibawah garis nol (0) ini menunjukkan tidak terjadi heteroskedastisitas.

Tabel 6. Uji Glejser

\begin{tabular}{|c|c|c|c|c|c|c|}
\hline \multicolumn{7}{|c|}{ Coefficients" } \\
\hline \multirow{2}{*}{\multicolumn{2}{|c|}{ Model }} & \multicolumn{2}{|c|}{ Unstandardized Coefficients } & \multirow{2}{*}{$\begin{array}{l}\text { Standardized } \\
\text { Coetricients } \\
\text { Beta }\end{array}$} & \multirow[b]{2}{*}{ T } & \multirow[b]{2}{*}{ Sige } \\
\hline & & 8 & std. Error & & & \\
\hline \multirow[t]{4}{*}{2} & [Constant] & 119 & 777 & & 153 & 879 \\
\hline & ROA & 2.890 & 5.014 & .087 & 377 & 707 \\
\hline & DER & .025 & 113 & .023 & .219 & 827 \\
\hline & NPM & 668 & 520 & 160 & 1.285 & 202 \\
\hline \multicolumn{7}{|c|}{ 3. Dependent Variable: A85 } \\
\hline
\end{tabular}

Dari tabel diatas menunjukkan nilai signifikan ROA (X1) 0,707, DER (X2) 0,827, NPM (X3) 0,202 dengan nilai signifikan diatas 0,05 maka disimpulkan tidak akan terjadi adanya heteroskedastisitas.

\section{Hasil Analisis Data Penelitian}

Tabel 7. Hasil Pengujian Regresi Linear Berganda

\begin{tabular}{|c|c|c|c|c|c|c|}
\hline \multicolumn{7}{|c|}{ Coefficients $^{a}$} \\
\hline \multirow{2}{*}{\multicolumn{2}{|c|}{ Model }} & \multicolumn{2}{|c|}{ Unstandardized Coefficients } & \multirow{2}{*}{$\begin{array}{c}\text { Standardized } \\
\text { Coefficients } \\
\text { Beta } \\
\end{array}$} & \multirow[b]{2}{*}{$\mathrm{t}$} & \multirow[b]{2}{*}{ Sig. } \\
\hline & & $\mathrm{B}$ & Std. Error & & & \\
\hline \multirow[t]{4}{*}{1} & (Constant) & 6.918 & 1.286 & & 5.381 & .000 \\
\hline & $\mathrm{ROA}$ & -39.737 & 8.300 & -.527 & -4.788 & .000 \\
\hline & DER & .019 & .188 & .009 & .103 & .918 \\
\hline & NPM & .494 & .861 & .063 & .573 & .568 \\
\hline
\end{tabular}

Harga saham = 6.918 - ROA 39.737 + DER 0.019 + NPM 0.494.

Hasil dari regresi linear berganda adalah sebagai berikut :

1. Nilai konstanta sebesar 6.918 menunjukkan apabila ROA, DER, NPM dianggap konstan atau bernilai nol (0) maka nilai harga saham perusahaan 6.918.

2. Koefisien ROA sebesar -39.737 menunjukkan apabila ROA naik satu persen, maka harga saham akan mengalami peningkatan -39.737 .

3. Nilai koefisien DER sebesar 0.019 menunjukkan apabila DER naik satu persen, 
maka harga saham akan mengalami peningkatam 0.019 .

4. Nilai koefisien NPM sebesar 0.494 menunjukkan apabila NPM naik satupersen, maka harga saham akan mengalami peningkatan 0.494 .

\section{Koefisien Determinasi Hipotesis}

Ghozali (2013: 95) menyimpulkan bahwasannya pengujian ini memiliki tujuan utuk memahami seluas apakah kemampuan model dalam menjelaskan variabel terikat .

Tabel 8. Hasil Uji Koefisien Determinasi

\begin{tabular}{|c|c|c|c|c|}
\hline \multicolumn{5}{|c|}{ Model Summary } \\
\hline Model & $\mathrm{R}$ & R Square & $\begin{array}{c}\text { Adposted } R \\
\text { Square }\end{array}$ & Std. Error of the Estimale \\
\hline 1 & $.494^{2}$ & 244 & 219 & 1.52478 \\
\hline \multicolumn{5}{|c|}{ a. Predictors (Constant), LNX3, LNX2, LNX1 } \\
\hline \multicolumn{5}{|c|}{ b. Dependent Variable: LNY } \\
\hline
\end{tabular}

Dari hasil tabel diatas diperoleh nilai adjusted R square (R2) koefisien determinasi adalah $0,219=21,9 \%$. Yang berarti sebesar $21,9 \%$ perubahan harga saham dapat dijelaskan dalam variabel ROA, DER dan NPM sedangkan sisanya 78,1\% yang dipengaruhi oleh variabel - variabel lain di luar variabel yang ditelitii.

Pengujian Hipotesis Secara Simultan (Uji F)

Ghozali ( 2013 : 96 ) Pengujian ini untuk mengetahui seluruh variabel indenpenden dapat mempengaruhi variabel dependen bersamaan.

\section{Tabel 9. Hasil Uji Hipotesis secara Simultan (Uji F)}

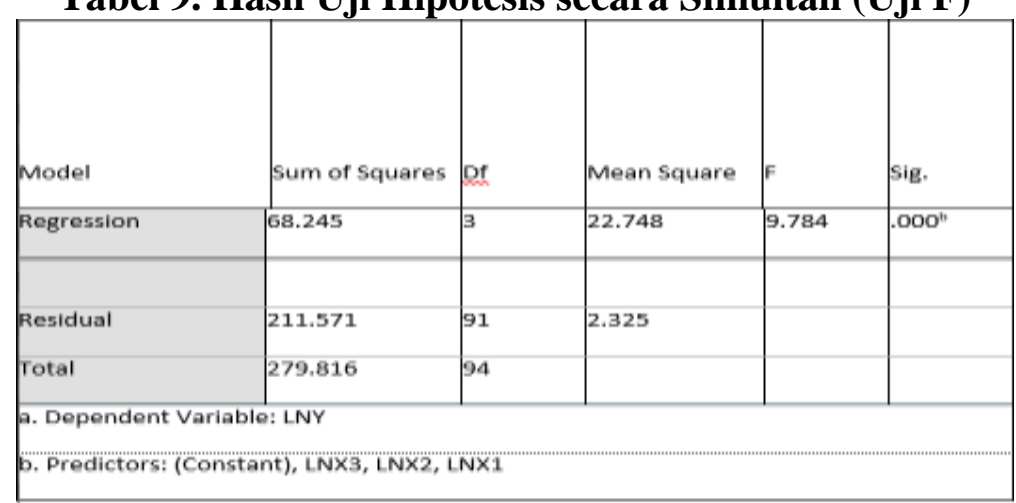

Pada hasil pengujian tabel diatas menunjukkan nilai Fhitung adalah sebesar 9,784 dan pada derajat bebas $1(\mathrm{df} 1=3)$ dan derajat bebas $2(\mathrm{df} 2)=\mathrm{n}-\mathrm{k}-1=95-3-1=91$. Nilai Ftabel pada tingkat kepercayaan signifikan 0,05 adalah 2,705. Oleh karena itu nilai Fhitung $\geq$ Ftabel $(9,784 \geq 2,705)$ dengan berarti bahwa variabel independent, ROA, DER, NPM secara simultan berpengaruh signifikan terhadap harga saham pada sektor keuangan (finance).

\section{Pengujian Hipotesis Secara Parsial (Uji T)}

Ghozali (2013:97) uji ini dilakukan untuk memahami seberapa berdampak variabel bebas terhadap variabel terikat. 
Tabel.10. Hasil Uji Statistik T

\begin{tabular}{|c|c|c|c|c|c|c|}
\hline \multicolumn{7}{|c|}{ Coefficients $^{a}$} \\
\hline \multirow{2}{*}{\multicolumn{2}{|c|}{ Model }} & \multicolumn{2}{|c|}{ Unstandardized Coefficients } & \multirow{2}{*}{\begin{tabular}{|l} 
Standardized \\
Coefficients
\end{tabular}} & \multirow[b]{2}{*}{$t$} & \multirow[b]{2}{*}{ sig. } \\
\hline & & $B$ & Std. Error & & & \\
\hline \multirow[t]{4}{*}{1} & (Constant) & 6.918 & 1.286 & & 5.381 & .000 \\
\hline & LNX1 & -39.737 & 8.300 & -.527 & -4.788 & .000 \\
\hline & LNX2 & .019 & .188 & .009 & .103 & .918 \\
\hline & LNX3 & .494 & .861 & .063 & .573 & .568 \\
\hline
\end{tabular}

Pada tabel diatas dapat kita lihat bahwa nilai t tabel untuk tahap signifikan $0,005(n-k)=$ 95-4 = 91 adalah sebesar 1.986 maka itu uji t dijelaskan sebagai berikut :

1. ROA (X1) pada harga saham (Y) didapatkan thitung sebesar 44.788 dan nilai signifikan 0.000 karena thitung -4.788 > 1.986 jadi Ho ditolak dan ha diterima berarti secara parsialROA berpengaruh negative dan signifikan.

2. DER (X2) pada harga saham (Y) didapatkan thitung sebesar 0.103 dan signifikan 0.000 karena thitung $0.103>1.986$ maka Ho diterima dan ha ditolak berarti secara parsial DER tidak berpengaruh signifikan.

3. NPM (X3) pada harga saham (Y) didapatkan thitung sebesar 0. 573 dan signifikan 0.568 karena thitung $0.573>1.986$ maka Ho diterima dan ha ditolak berarti secara parsial NPM tidak berpengaruh signifikan.

\section{SIMPULAN DAN SARAN}

\section{Simpulan}

1. Pengujian secara parsial (uji $\mathrm{T}$ ) terhadap ROA berpengaruh negatif dan signifikan terhadap harga saham, sedangkan DER, dan NPM tidak berpengaruh signifikan terhadap harga saham pada sektor keuangan (finance) yang terdaftar di BEI periode 2015-2019.

2. Sementara itu, pengujian secara simultan( uji F) ROA, DER, dan NPM berpengaruh signifikan terhadap harga saham pada sektor keuangan (finance) yang terdaftar di BEI periode 2015-2019.

\section{Saran}

Pengujian secara parsial (uji $\quad$ T) terhadap ROA berpengaruh negatifdan signifikan terhadap harga saham, sedangkan DER, dan NPM tidak berpengaruh signifikan terhadap harga saham pada sektor keuangan (finance) yang terdaftar di BEI periode 2015-2019.

Sementara itu, pengujian secara simultan (uji F) ROA, DER, dan NPM berpengaruh signifi kan terhadap harga saham pada sektor keuangan (finance) yang terdaftar di BEI periode 2015 - 2019 .

Saran bagi para investor dan calon investor, kami mengharapkan agar lebih menganalisis laporan keuangan sebagai gambaran dalam pengambilan keputusan dan tidak hanya mengandalkan analisis rasio yang peneliti lakukan. Karena masih banyak faktor lain yang tidak kami sebutkan dalam penelitian ini yang dapat menggambar kan nilai atau keadaan suatu perusahaan

Saran bagi peneliti selanjutnya untuk memperbanyak jumlah sampel,variabel, serta periode agar penelitian selanjutnya memiliki data yang lebih akurat lagi. 


\section{DAFTAR PUSTAKA}

Bayu Wulandari,dkk (2020). "Pengaruh ROE, CR, TATO, NPM Terhadap Harga Saham PadaPerusahaan Manufaktur Sub Customer Goods yang terdaftar di Bursa Efek Indonesia".

Fahmi, Irham. (2017). Pengantar Manajemen Keuangan Teori dan Soal Tanya Jawab.Bandung :Alfabeta.

Faizal Ali Satriawan, Sri Utiyati. (2019). Pengaru ROA, DER, NPM Terhadap Harga SahamPada Perusahaan Telekomunikasi. Jurnal Ilmu dan Riset Manajemen 8 (10) : 11.

Fikri Zamzami, Nanu Hasanuh. (2021) Pengaruh Net Profit Margin, Return On Asset, Return OnEquity dan Inflasi terhadap Harga Saham.

Hanson Sainan, Phillip, Winson Halim. (2019). Pengaruh Rasio Profitabilitas, Solvabilitas, dan Likiuditas Terhadap Harga Saham Pada Perusahaan Sektor Pertambangan Yang Terdaftar di BEI Periode 2014- 2018. Riset \& Jurnal Akuntansi $3(2): 131$.

Hantono. (2020). Pengaruh Current Ratio, Debt to Equity Ratio, Firm Size Terhadap Net Profit Margin Pada Perusahaan Perdagangan Besar Produksi yang Terdaftar di BEI. STATERA : Jurnal Akuntansi dan Keuangan.

Hottua Samosir, dkk. Pengaruh Current Ration (CR), Net Profit Margin dan Kebijakan Dividen terhadap Harga Saham pada Perusahaan Consumer Goods yang Terdaftar di Bursa Efek Indonesia ( BEI ) Pada Periode 2013-2017.

Https://www.idx.co.id/

Januardin Manullang, Nanda Pratiwi, Reiensa Yohana Sihombing, Rifka Aulia Harahap, Kevin Christian Tampubolon. (2021). Pengaruh Return on Asset, Net Profit Margin dan Current Ratio Terhadap Harga Saham Food and Beverage di Bursa Efek Indonesia.

Jenni, Lau Yeni, Merissa, Trisha Wanny, Erlin, Isna Asdiani Nasution (2019). Pengaru TATO, DER, dan Current Ratio terhadap ROA pada Prusahaan Property dan Real Estate.

Jessica Tanri, Francroyce Zulion, Behrry, Liviaty Vandana, Ira Martika Winarno, Adam Afiezan.(2020). Pengaruh Current Ratio, Net Profit Margin, Stabilitas Penjualan dan Struktur Aktiva terhadap Struktur Modal di BEI Perioe 2014-2017.

Keumala Hayati, Antonius KAP Simbolon,dkk.(2013). Pertumbuhan Penjualan terhadap Harga Saham pada Perusahaan Manufaktur yang terdaftar di Bursa Efek Indonesia periode 2013- 2017.

Keumala Hayati, Renita Ferawati Lumban Gaol, dkk. (2019). Pengaruh Inventory Turnover, Sales Growth dan Liquidity Terhadap Profitabilitas pada PT. Sumber Alfaria Trijaya Tanjung Morawa periode 2013-2017.

Nanda Pratiwi, Refiensa Yohana Sihombing, dkk. (2021). Pengaruh ROA,NPM dan CR Terhadap Harga Saham Food and Beverage di Bursa Efek Indonesia. Riset dan Jurnal Akuntansi 5 (1):120.

Rika Wani Juwita, Yois Nelsari Malau. (2020). Pengaruh CR, Total Asset Turnover, NPM, Terhadap Perubahan Laba Pada Peruahaan Perdagangan Jasa dan Investasi yang Terdaftar di Bursa Efek Indonesia Periode 2014-2017. JIMEK : Jurnal Ilmiah Mahasiswa Ekonomi. 
Silvia Sarina, Aprilia Lubis, Linda. (2020). Pengaruh Ukuran Peursahaan, DER,ROE,dan CR untuk Mengidentifikasi Financial Distress Pada Perusahaan Properti yang terdaftar diBursa Efek Indonesia Periode 2014-2017. Riset dan Jurnal Akuntansi.

V. Wiratna Sujarweni. Manajemen Keuangan Teori Aplikasi dan Hasil Penelitian. Yogyakarta : Pustaka Baru Press. 